\title{
The Role of Public Private Partnerships in Planned and Serviced Land Delivery in Tanzania
}

\author{
Samson Elisha Kasala, Marco Mathias Burra \\ Department of Urban and Regional Planning, Ardhi University, Dar es Salaam, Tanzania \\ Email: samson.kasala@gmail.com
}

Received 8 January 2016; accepted 4 March 2016; published 7 March 2016

Copyright (C) 2016 by authors and Scientific Research Publishing Inc.

This work is licensed under the Creative Commons Attribution International License (CC BY).

http://creativecommons.org/licenses/by/4.0/

(c) (†) Open Access

\begin{abstract}
A century (1890s to 1990s) of urban development planning and management in Tanzania has witnessed, among other things, a growing demand for planned and serviced land in urban areas. In response, the planning machinery has attempted to reduce the chronic gap between demand and supply of planned land, albait in vain. The methodology adopted involved a review of secondary data sources, interviews and analysis. The findings of this research present a multidimensionally reciprocating role of Private Public Partnerships (PPP) in the delivery of planned and serviced land in Tanzania. Taking the role of Private Public Partnerships into account, effective implementation of urban development planning and management proposals is alternatively possible using resources amalgamated through workable Public Private Partnerships.
\end{abstract}

\section{Keywords}

Planning, Surveying, Engineering, Services, Projects

\section{Introduction}

Urban planning activities in Tanzania generally and Dar es Salaam specifically, are governed by the Tanzania's Urban Planning Act No. 8 of 2007 [1]. The legislation requires that urban planning is carried out to guide land development and provision of service infrastructure. A century (1890s to 1990s) of urban planning practice in Tanzania, has witnessed urban planning being treated as an activity of the government, executed by planning departments in local authorities. This has been the case but with limited participation of the private sector, stakeholders from other government departments, and the popular sector. Resulting from such a practice, local authorities have found themselves not been able to meet demands for planned, surveyed and serviced land in Tanzania. 
In order to reduce the widening gap between demand and supply of planned, surveyed and serviced land in Tanzania, the government (public sector) allowed, under the Urban Planning Act No. 8, 2007, other stakeholders particularly the private and popular sectors to take part in land development or land value addition through planning, surveying and service delivery in Tanzania. Public Private Partnership (PPP) as an approach to planning and service delivery has been practiced in different parts of the world (see for example [2]-[4]). Land development through Public Private Partnership-based planning, surveying and infrastructure provision has continued to be practised in cities of developing countries worldwide (see for example [5]-[8]). The purpose of this paper is to examine the role and contribution of the private sector in planning, surveying and servicing of urban land in Tanzania. The term land development in this paper is used to mean planning, surveying, and vehicular accessibility improvement.

\section{Methodology}

The role of public private partnerships (PPP) in the delivery of planned, surveyed and serviced land in Tanzania, has been examined by eventualising the process through which activities are conducted. The process involves: identification of planning areas in liaison with relevant local authorities; land acquisition, preparation of town planning drawings and approval, land surveying and approval, opening up roads to improve accessibility, and marketing of planned and serviced land.

\subsection{Identification of Planning Areas}

Town planning firms liaise with local authorities by submitting expression of interests to plan, survey, and open up roads within the planning area. Upon demand, local authorities invite the appliying town planning firms to conduct activities they have applied for. This process takes between one to four weeks.

\subsection{Land Acquisition}

This is done in two ways. First, is by way of buying land from willing sellers. The bought land becomes a property of the buyer. Secondly, when land for purchase is not available, planning firms enter into contracts with individual land owners. Through this arrangement, the later allows planning firms to plan, survey land and open up roads within the planning areas. This process takes between one to two months.

\subsection{Town Planning, Surveying and Access Improvement}

Town planning starts with detail picking and preparation of a basemaps. The later is then used to guide the design of a particular area. Accepted town planning drawings are submitted to relevant authorities for approval. An approved town planning drawing is then used to recruit a land surveyor. The surveyor applies for all the necessary survey permits and conducts cadastral survey in accordance with the approved town planning drawing. Accepted survey plans are submitted to relevant authorites for approval. An approved survey plan is used by an engineer to improve access by oppening up new roads within the planning area. The land development activities involving planning, surveying and access improvement take an average of three to four months.

\subsection{Marketing of Surveyed Plots}

Plots produced through the process involving planning, survey and engineering, are then sold to the public and other Clients available. Clients for plots have involved private companies, private and public institutions, parastotal organisations including social security funds, etc. Marketing is conducted either by the plot owner directly, through a local authority, or a partner Bank. Currently the Commercial and Rural Development Bank (CRDB), Azania Bank, Women Development Bank, Watumishi Housing Company, Public Pensions Funds, Institutions, private companies and the entire public are among reliable partners with private firms in the marketing of planned, surveyed and serviced land in Tanzania.

\section{Findings: The Role of Public Private Partnerships in Planned Land Delivery}

\subsection{The Public Sector's Response on Demands to Planned, Surveyed and Serviced Land}

Previous research on housing policy in Tanzania have shown trends of severe shortage of planned and surveyed 
land and or plots in Tanzania and Dar es Salaam City in particular (Figure 1). For example, Lupala [9] quoting Kironde [10] shows that between 1977 and 1986 the demand for surveyed residential plots was at 212,446 plots. Then, the Dar es Salaam City Council managed to produce only 20,564 plots. This was equivalent to 9.7 percent of the recorded demand. Between 1978 and 1991, the Ministry of Lands, Housing and Human Settlements Development (MLHHSD) allocated only 25,042 plots in response to 358,468 plot applications it had received. This was equivalent to 6.9 percent of total applications per annum ${ }^{1}$. Generally, the number of surveyed plots dropped from 22,000 in 1972 to 2300 in $2001^{2}$. This means that the supply met about $10 \%$ of total demand for surveyed plots [11]. As per Figure 1, there was a glaring plot deficit from 1994 to 1996. This situation has spurred unguided city growth particularly in the peri-urban areas of Dar es Salaam. Figure 1 shows proportions of plots applied for and those allocated in Dar es Salaam between 1979 and 1998.

By 2002, the demand for planned, surveyed and serviced plots had doubled. That is from 358,468 to between 600,000 and 800,000. Responding to the shortage, the public sector, through the Ministry of Lands, Housing and Human Settlements Development (MLHHSD) supplied 20,000 plots in Dar es Salaam. This amount of plots accounted for only $3 \%$ of the recorded demand. In this case, the supply of plots had dropped from $10 \%$ in 2001 to $3 \%$ in 2002. The inadequate supply of plots spurred: i) informal settlements growth in peri-urban areas and, ii) corruption practices in the lands sector too.

\subsection{The Private Sector's Response on Demands to Planned, Surveyed and Serviced Land}

The private sectors' involvement in land development through the production of planned, survey and srviced plots began way back in 2002. For the period ranging from 2002 to 2012 the private sector had delivered about 68,000 plots in Dar es Salaam region alone. Later, a total of other 32,650 plots were produced between 2013 and May 2015. This means from 2002 todate the private sector has producd more than 100,000 plots in Dar es Salaam and other regions (Tabel 1).

Such a substantial supply of planned and serviced plot was made possible through the involvement of more than 108 private firms, in association with local authorities, Commercial Banks, Public Pensions Funds, Private companies, and Ministry of Land Housing and Human Settlements Development to mention but a few. Whereas the firms involved were town planning, land surveying and engineering by profession, key players on the Banking sectors were Commercial and Rural Development Bank (CRDB), Azania, and Women Development Banks.

In principle, the town planning firms have been initiating the planning process that ends up with the delivery

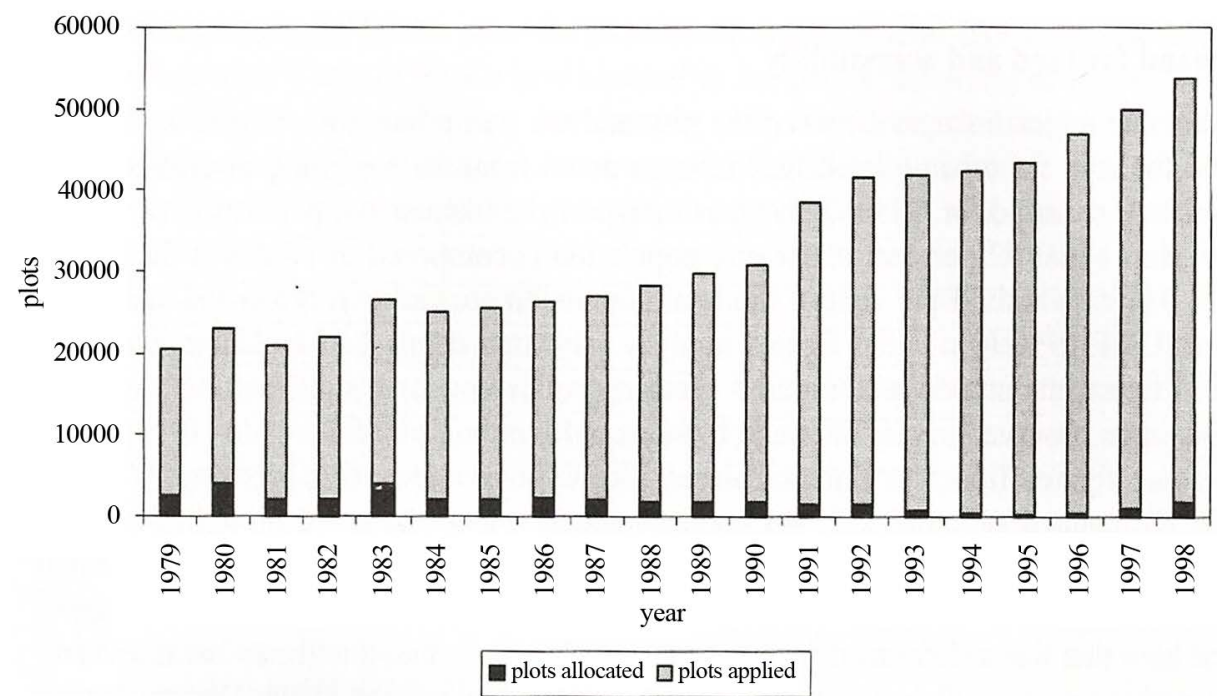

Figure 1. Plot applications and allocations in Dar es Salaam 1979-1998, Source: Lupala [4] quoting Kironde [9]: Plots allocated by the Dar es Salaam City Commission.

\footnotetext{
${ }^{1}$ Data from the Ministry of Lands Housing and Human Settlements Development, 2009.

${ }^{2}$ Data from a research on "the impact of the Regulatory Framework on Access to Legal Shelter in Tanzania, 1998. The research reveals "major lack of capacity (resources) to acquire land, survey and allocate plots to meet demand in urban areas" as the reason for such a drop back in number of plots.
} 
Table 1. Contribution of the private sector on planned and serviced land delivery.

\begin{tabular}{|c|c|c|c|}
\hline $\mathrm{S} / \mathbf{n}$ & Planning Firm & Planning/local Authority & No. of plots \\
\hline 1 & Ardhi Plan & Temeke Municipal Council & 13,000 \\
\hline 2 & Ardhi Plan & Kinondoni Municipal Council & 1500 \\
\hline 3 & Ardhi Plan & Ilala Municipal Council & 500 \\
\hline 4 & Ardhi Plan & Morogoro Municipal Council & 6500 \\
\hline 5 & Ardhi Plan & Kibaigwa District Council & 3000 \\
\hline 6 & Ardhi Plan & Capital Development Authority (CDA) Dodoma & 10,000 \\
\hline 7 & Conreeb/Ardhi Plan & Singida Municipal Council & 4000 \\
\hline 8 & Ardhi Plan & Tabora Municipal Council & 8500 \\
\hline 9 & Conreeb & Kahama Town Council & 8000 \\
\hline 10 & Conreeb & Igunga District Council & 1000 \\
\hline 11 & Ardhi Plan & Babati District Council & 4000 \\
\hline 12 & Conreeb & Sumbawanga Municipal Council & 4300 \\
\hline 13 & Ardhi Plan & Kilosa District Council & 700 \\
\hline 14 & Ardhi Plan & Mwanza City Council & 2300 \\
\hline 15 & Ardhi Plan & Geita District Council & 250 \\
\hline 16 & Nela Oceanic/Ardhi Plan & Mkuranga District Council & 600 \\
\hline 17 & Ardhi Plan & Songea Minicipal Council & 18,000 \\
\hline 18 & Makazi Consults & Lindi Municipal Council & \\
\hline 19 & Ardhi Plan & Kibaha Town Council & 6000 \\
\hline 20 & Ardhi Plan & Bagamoyo District Council & 8500 \\
\hline \multicolumn{3}{|r|}{ Total } & 100,650 \\
\hline
\end{tabular}

Source: Field check, May 2015.

of approved town planning drawings. Approved town planning drawinga are then used to engage land surveyors to survey land according to the approved town planning drawings. The completion of survey activities including approval of survey plans, marks the beginning of engineering activities. The later, deals with opening up and/or improving vehicular access into the planning area. When survey and engineering works are completed, the plots produced are sold to the general public either by the owners, a local authority within which the project has been implemented or a partner Bank.

\section{The Merits of Public Private Partnerships in Tanzania}

The delivery of planned, surveyed and serviced land through public private partnerships (PPP) has been in practice in different parts of the world (see for example [12] and [5]. In the Tanzanian context, the implementation of land development projects by ways of planning, surveying, and access improvement under PPP has generated various merits as elaborated hereunder:

\subsection{Resource Saving by Planning Authorities}

The private sector has been implementing land development projects through planning, surveys, and opening roads by using their own resources. On the other hand, local authorities have been playing a coordinating and regulatory role at minimum cost. The fact that such projects are implemented largely using the private sector resources, brings a resource saving component on the local authorities'side. The resources that would have been used by a local authority to execute such a project is saved and used for other service delivery projects. 


\subsection{Acquiring Areas for Public Services at Zero Cost}

Under the public private partnerships arrangement for land development, local authorities have been acquiring areas for public service for free, that is... "without paying compensation costs". Under this arrangement, the cost for acquiring such lands for roads, open spaces, cemeteries, public buildings etc, is born by land owners and the private sector. Land owners and the private firms are required by law to provde areas for public services as part of their project's contribution to social development (Corporate Social Resibonsibility). On the side of local authorities, the financial resources that would have been used to pay compensantion are alternatively used in other social development projets including health, water supply, education etc.

\subsection{Land Use Conflicts Resolution and Squatters Mitigation}

The implementation of planned land delivery projects through the PPP arrangement in Tanzania, has addressed landuse conflicts based on boundary disputes. While customary boundaries are abandoned, new ones are introduced based on a survey plan. The new boundaries maintain the same land sizes owned before implementation of a planning and survey project. This practice has led to reduction of existing and mitigation of future land use conflicts in project areas. Related to that, the arrangement has been instrumental in delivering planned land on the one hand, and preventing further expansion of squartters in fast growing areas, on the other.

\subsection{Enhanced Revenue Collection}

A planned, and surveyed land is technically registered. Thus it is by law, due for taxation. The production of planned, surveyed and serviced land allows the government and local authorities to improverevenue collection through levying land rent, and other statutory taxes such as value added tax when purchase and transfer of land is executed.

\subsection{Enhanced Professional Synergies}

Through the Public Private Partnership arrangement, new areas for stakeholder cooperation have been identified. One of such areas is cost sharing. Participating professional firms involving planning, surveying and, engineering share the costs for project implementation. Each portion of a project is executed by a relevant profession using its own resources. The pulling together of resources from participating professional firms ensures not only project cost sharing but also risk redistribution. Experience from projects implemented in various regions (refer Table 1) shows that cost sharing and risk redistribution rely heavily on mutual trust and professional competence between and among parties involved.

\subsection{Discovering Community Development Potentials}

Public Private Partnership-based land development projects in Tanzania have exposed development potentials in urban communities. Individuals or groups in such communities have accessed land, built houses, and invested in the provision of service infrastructure including roads, water, electricity and sewerage, with minimum support from the governmnet. If urban community members are capable of commiting resources to such expensive and permanent investments, they also can invest successfully and profitably in land development projects. The abundant resources available in our local communities present a huge potential that needs to be utilised to ensure effective urban development planning and management in Tanzania

\section{Challenges}

The implementation of land development projects through Public Private Partnerships has been possible albeit with a number of challenges.One of such challenges is the lack of common interest in town planning. When a lands development project is implemented in an area involving multiple land owners, their interests, preferences and choices tend to vary significantly. While one section of land owners would be interested in planning, the other wouldn't. This situation calls for consulted efforts to bring key land owners to a level of understanding so that they can build interest in planning. The second challenge is inadequate awareness on the utility of planning, surveying and land servicing. Some land owners are notably apprehensive of engaging in Public Private Partnership-based land development projects. This comes from the fact that PPP is an arrangement that is still 
new to majority land development stakeholders, politicians and land owners in particular. This again calls for massive awarenes raising campaigns to enlighten the public on ensuing forms and approaches to urban land development in Tanzania. Awareness campaigns will clear the negative image being painted against the Public Private Partnership approach amid political and professional veiled interets

\section{Discussion}

Successful implementingation of land development projects through public private partnerships (PPP) depends on active participation of two groups of stakeholders. In the context of this research, the stakeholders are professional firms, their partners, and financial institutions on the one hand, as well as local authorities and land owners on the other. Mechanisms have to be put in place to ensure that stakeholders are actively and adequately involved in spearheading the PPP-based land development process. Active stakeholder participation has to be a continous process that must be intensified when new rounds of urban development challenges emerge.

The use of public private partnerships in facilitating land development and service provision in particular, has worked through several modes in Africa, Asia, Europe and America [12] [13]. The partnership models include: Supply and management contracts, Turn-key projects; Lease, Concessions, Private ownership of assets. The commonly used arrangements in these modes of partnerships are: a) Build-Operate-Transfer b) Build-OwnOperate, c) and Private Finance Initiative (a more recent innovation). These forms of public private partnerships are elaborated hereunder with a view to identifying the one that fits the land development projects being implemented through PPP in Tanzania.

\subsection{Build-Operate-Transfer}

This is a concession-form of Public-Private Partnerships . In this form of partnership, the Government defines and grants specific rights to an entity (usually a private company) to build and operate a facility for a fixed period of time. The Government may retain the ultimate ownership of the facility and/or right to supply the services. The Build-Operate-Transfer or BOT has its other variants. These are: Build-Transfer-Operate (BTO), Build-Rehabilitate-Operate-Transfer (BROT), and Build-Lease-Transfer (BLT). In any of these forms of BOT, the concessionaire undertakes investments and operates the facility for a fixed period of time after which the ownership reverts back to the public sector. In this type of arrangement, operating and investment risks can be substantially transferred to the concessionaire. However, in a BOT type of model the government has explicit and implicit contingent liabilities that may arise due to loan guarantees provided and default of a sub-sovereign government and public or private entity on non-guaranteed loans. By retaining ultimate ownership, the government controls policy and can allocate risks to those parties best suited to bear them or remove them [12].

\subsection{Build-Own-Operate}

In the Build-Own-Operate (BOO) type and its other variants such as Design-Build-Finance-Operate, the private sector builds, owns and operates a facility, and sells the product/service to its users or beneficiaries. This is the most common form of private participation in investment projects in many countries.

\subsection{Private Finance Initiative (PFI)}

In the Private Finance Initiative (PFI) model, the private sector, similar to the Build-Own-Operate (BOO) model builds, owns and operates a facility. However, the public sector (unlike the users in a BOO model) purchases the services from the private sector through a long-term agreement. Private Finance Initiative (PFI) projects therefore, bear direct financial obligations to government in any event. In addition, explicit and implicit contingent liabilities may also arise due to loan guarantees provided to lenders and default of a public or private entity on non-guaranteed loans. In the PFI model, asset ownership at the end of the contract period may or may not be transferred to the public sector.

As elaborated earlier, the model used in implementing land develeopment projects through Public Private Partnershipsin Tanzania, involves three parties. They include: the professional firms (representing the private sector through private companies), the government (representing the public sector through local authorities) and land owners (representing the popular sector). Existing arrangements provide that, the private sector initiates land development projects by using its own professionalism and resources. In this case the private sector shoul- 
ders all risks and liabilities that may arise in the course of implementing the project. The government on the other hand, retains the ultimate regulatory role in the project implementation process. In its core activities, the private sector adds value to the identified areas by ways of planning, surveying, and paving roads. Thereafter, the private sector sells a portion of the project outputs in order to recover investment costs. The selling component brings in marketing specialists including institutions and private firms. Viewed from that perspective, the Puplic Private Partnership (PPP) based land development arrangement in Tanzania does not subscribe to only one of the PPP models discussed above. Rather, it subscribes to more than one of those. In that context it uses a combination of elements borrowed from each of the models outlined above. That being the case, it is an enhanced or hybridised form of public private partnership. Other things being equal, it is expected to provide the best results than any of the approaches in isolation.

\section{Conclusion}

Before the introduction of Public Private Partnerships (PPP), the government and local authorities had difficulties in developing land by ways of planning, surveying and providing services. With the engagement and commitment of the private sector, the delivery of land development services is becoming a simplified undertaking that benefit the parties involved. First, local authorities benefit in terms of: accessing areas for public services freely, money saving, technology transfer, enhancing revenue collection, and ultimately delivering planned and serviced land. This ensures planned and serviced land development that prevents expansion of squarter settlements. Secondly, while the private sector benefits both professionally and financially, land owners benefit in terms of value addition on their land, addressing land use conflicts, and having their lands registered. The role of the private sector in generation of these benefits is undoubtedly critical and cannot be overemphasized. Viewed from that perspective, the delivery of land development services is potentially effective with the Public Private Partnerships arrangement than it has been with the government alone.

\section{Acknowledgements}

The authors wish to thank all those whose support had a contribution in the production of this paper. Included in the list of valuable support are Local Authorities, Partners in urban land development, Land owners, and Local leaders. Equally important is the financial support from Conreeb Company LTD which was instrumental in accomplishing this research.

\section{References}

[1] URT (2007) The Urban Planning Act No. 8 of 2007. Dar es Salaam.

[2] Choguill, C. (1997) Ten Steps to Sustainable Urban Infrastructure. The Urban Age, 5.

[3] Albrechts, L. (2004) Strategic (Spatial) Planning Reexamined. Environment and Planning B: Planning and Design, 31, 743-758.

[4] Kasala, S.E. (2013) Operationalizing Strategic Urban Development Planning: A Case of Dar es Salaam City, Tanzania. Unpublished Ph.D Thesis, University of Dar es Salaam, Dar es Salaam.

[5] Giddings, B. and Hopwood, B. (2006) From Evangelistic Bureaucrat to Visionary Developer: The Changing Character of the Master Plan in Britain. Planning Practice and Research, 21, 337-348. http://dx.doi.org/10.1080/02697450601090849

[6] Albrechts, L. (2001) In Pursuit of New Approaches to Strategic Spatial Planning. A European Perspective. International Planning Studies, 6, 293-310.

[7] Halla, F. and Majani, B. (1999) Innovative Ways for Solid Waste Management in Dar es Salaam: Towards Stakeholder Partnerships. Habitat International, 23, 351-361. http://dx.doi.org/10.1016/S0197-3975(98)00057-5

[8] Kombe, W. and Kreibich, Eds. (1997) Decentralised Development and Prospects of Planning in Africa. Spring Research Series, Dortmund.

[9] Lupala, A. (2002) Peri-Urban Land Management for Rapid Urbanization: The Case of Dar es Salaam: Spring Research Series. Dortmund.

[10] Kironde, J. (1994) The Evolution of the Land-Use Structure of Dar es Salaam, 1890-1990. Doctoral Thesis, University of Nairobi, Nairobi.

[11] UCLAS (1998) The Impact of the Regulatory Framework on Access to Legal Shelter in Tanzania. UCLAS, Dar es Sa- 
laam.

[12] Payne, G. (1999) Public/Private Partnerships in Land for Housing. In: Payne, G., Ed., Making Common Ground: Public/Private Partnerships in the Provision of Land for Housing. Intermediate Technology Publications, London, 1-16.

[13] Ogu, V. (2000) Stakeholders’ Partnership Approach to Infrastructure Provision and Management in Developing World Cities: Lessons from the Sustainable Ibadan Project. Habitat International, 24, 517-533. http://dx.doi.org/10.1016/S0197-3975(00)00015-1 